\title{
Laser Ablation radiocarbon analysis of a high alpine stalagmite - a hint to an old organic carbon pool?
}

\section{Other Conference Item}

Author(s):

Welte, Caroline (D); Fohlmeister, Jens; Wacker, Lukas; Wertnik, Melina; Spötl, Christoph; Yeman, Christiane; Hattendorf, Bodo; Christl, Marcus (D); Eglinton, Timothy I.; Synal, Hans-Arno (D)

\section{Publication date:}

2020-05-08

\section{Permanent link:}

https://doi.org/10.3929/ethz-b-000456951

\section{Rights / license:}

Creative Commons Attribution 4.0 International

Originally published in:

EGUsphere, https://doi.org/10.5194/egusphere-egu2020-7298 
EGU2020-7298, updated on 18 Dec 2020

https://doi.org/10.5194/egusphere-egu2020-7298

EGU General Assembly 2020

(c) Author(s) 2020. This work is distributed under

the Creative Commons Attribution 4.0 License.

\title{
Laser Ablation radiocarbon analysis of a high alpine stalagmite - a hint to an old organic carbon pool?
}

\author{
Caroline Welte ${ }^{1,2}$, Jens Fohlmeister ${ }^{3}$, Lukas Wacker ${ }^{1}$, Melina Wertnik ${ }^{1,2}$, Christoph Spötl $^{4}$, Christiane \\ Yeman $^{1}$, Bodo Hattendorf ${ }^{5}$, Marcus Christl ${ }^{1}$, Timothy I. Eglinton ${ }^{2}$, and Hans-Arno Synal ${ }^{1}$ \\ ${ }^{1}$ Laboratory of Ion Beam Physics, ETH Zürich, 8093 Zurich, Switzerland \\ ${ }^{2}$ Geological Institute, ETH Zürich, 8092 Zurich, Switzerland \\ ${ }^{3}$ Potsdam Institute for Climate Impact Research (PIK) e.V., 14473 Potsdam, Germany \\ ${ }^{4}$ Institute of Geology, University of Innsbruck, Austria \\ ${ }^{5}$ Laboratory of Inorganic Chemistry, ETH Zürich, 8093 Zurich, Switzerland
}

A novel technique making use of laser ablation coupled online to accelerator mass spectrometry (LA-AMS) allows analyzing the radiocarbon concentration $\left(\mathrm{F}^{14} \mathrm{C}\right)$ in carbonate samples at a spatial resolution down to $\sim 100 \mu \mathrm{m}$ within very short analysis times [1]. This new technique can provide radiocarbon data close to the spatial resolution of stable carbon isotope measurements and, thus, can help to interpret $\delta^{13} \mathrm{C}$ signatures, which otherwise are difficult to understand [2]. Conventional analytical methods applied to stalagmite samples for ${ }^{14} \mathrm{C}$ analysis, where a micro-sample is drilled or milled and carbon is liberated by the addition of phosphoric acid provide exclusively the isotope composition of the $\mathrm{CaCO}_{3}$, but not of organic matter also captured in stalagmites. LA-AMS allows accessing the ${ }^{14} \mathrm{C}$ concentration of both materials opening up new opportunities for gaining insights into vegetation and soil dynamics.

SPA-127 is a stalagmite from Spannagel cave (W Austrian Alps) that grew between 8500 and 2500 a $\mathrm{BP}$ at an average rate of $25 \mu \mathrm{m} / \mathrm{a}$ [3]. $\delta^{13} \mathrm{C}$ and ${ }^{14} \mathrm{C}$ were analyzed with high resolution along the full range of the $15 \mathrm{~cm}$ long specimen. During LA-AMS ${ }^{14} \mathrm{C}$ analysis, positive anomalies in ion currents were observed in the older stalagmite section. These comparably higher $\mathrm{CO}_{2}$ conversion efficiencies are associated with organic materials compared to $\mathrm{CaCO}_{3}$ during LA. Lower $\mathrm{F}^{14} \mathrm{C}$ were observed along with these anomalies. The signal structure could be reproduced both after removing $\sim 0.5 \mathrm{~mm}$ of the carbonate surface layer and on the stalagmite's archive slab making possible contamination unlikely. So far, we deduce that the observed anomalies are caused by several flushing events in the early Holocene, in which ${ }^{14} \mathrm{C}$ dead organic components (acids) entered the cave and were incorporated into the stalagmite matrix. Due to the high elevation of the cave and cold conditions during the glacial, the ancient organic acids most likely stem from the Eemian and were stored in the host rock.

[1] C. Welte, et al., (2016). Anal. Chem., 88, 8570- 8576.

[2] F. McDermott, (2004). Quat. Sci. Rev., 23, 901-918. 
[3] Fohlmeister J. et al., (2013). Holocene, 23, 749-754. 